\title{
OPMERKINGEN EN AANTEKENINGEN
}

\section{Prijsvraag.}

De Nederlandse Orde van Accountants heeft ter gelegenheid van haar tweede lustrum een prijsvraag uitgeschreven, waarbij van de deelnemers wordt gevraagd:

Het aangeven van oplossingen voor de vraag op welke wijze een doelmatige vereenvoudiging zou kunnen worden bereikt van de administratieve en formele voorschriften, waarmede het bedrijfsleven in verband met de uitvoering van de sociale verzekeringswetten is belast, een en ander onder handhaving van de materiële positie van de verzekerde.

Deelneming staat voor een ieder open.

Inzendingen worden beoordeeld door een jury, bestaande uit:

Prof. Mr. J. J. M. van der Ven, voorzitter

Prof. Mr. N. E. H. van Esveld

Prof. Mr. W. F. de Gaay Fortman.

Een toelichting op deze prijsvraag, en verder van belang zijnde gegevens worden op aanvraag toegezonden door het secretariaat van de Nederlandse Orde van Accountants, Prinsengracht 721, Amsterdam, C.

\section{Cahiers économiques de Bruxelles.}

In België is als publicatie van het Département d'Economie Appliquée de l'Université Libre de Bruxelles een nieuw driemaandelijks tijdschrift verschenen: de "Cahiers économiques de Bruxelles". Het is voornamelijk gewijd aan statistische onderzoekingen op macro-economisch gebied. De afleveringen van oktober 1958 en januari 1959 bevatten o.m. de vol. gende artikelen: Dix années de comptabilité nationale (1948-1957); La Belgique à l'aube du marché commum; La politique économique belge de 1954 à 1957; Le tableau d'input-output de la Belgique; L'Analyse des revenus (1948-1957); L'Evolution de la quantité de travall; Un modèle économétrique belge; Quelques réflexions sur la réforme de la fiscalité belge. 